\title{
Factors influencing the absorption of iron from soya-bean protein products
}

\author{
BY D. P. DERMAN, D. BALLOT, T. H. BOTHWELL*, \\ B. J. MACFARLANE, R. D. BAYNES, A. P. MACPHAIL, M. GILLOOLY, \\ J. E. BOTHWELL AND W. R. BEZWODA
}

Joint University/South African MRC Iron and Red Cell Metabolism Unit, Department of Medicine, University of the Witwatersrand Medical School, 7 York Road, Parktown, Johannesburg 2193, South Africa

AND F. MAYET

Department of Medicine, University of Natal Medical School, Congella, Durban, South Africa

(Received 19 August 1986 - Accepted 9 January 1987)

1. The absorption of iron from soya-bean (Glycine hispida)-based and milk-based infant formulas was assessed in 138 multiparous Indian women, using the erythrocyte utilization of radioactive Fe method.

2. Fe absorption was significantly greater from the basal milk formula ( $1.5 \mathrm{~g}$ protein) than it was from the basal soya-bean formula ( $2.3 \mathrm{~g}$ protein), with geometric mean values of 0.083 and 0.044 respectively.

3. Ascorbic acid markedly increased Fe absorption from the milk-based formula in a dose-dependent fashion. The increase was fivefold when the ascorbic acid: Fe ratio on a weight-for-weight basis was $6: 1$ and over tenfold when it was $20: 1$. In contrast, ascorbic acid had a less-marked effect on the absorption of Fe from the soya-bean-based formula, with only a two- to threefold increase at an ascorbic acid: Fe ratio of $20: 1$.

4. The geometric mean Fe absorption from the soya-bean formula ( $1 \cdot 27 \mathrm{mg} \mathrm{Fe}, 2 \cdot 3 \mathrm{~g}$ isolated soya-bean protein (ISP)) was somewhat less than that from the same amounts of ISP and ascorbic acid made up in milk (0.075 and 0.113 respectively). However, a direct comparison between the soya-bean formula in milk and in water showed no significant difference $(0.043$ and 0.060 respectively).

5. Fe absorption from a drink containing $10 \mathrm{~g}$ ISP and $30 \mathrm{mg}$ ascorbic acid was significantly better than that from a similar drink containing the soya-bean flour from which ISP is extracted $(0.044$ and 0.027 respectively).

6. Heating ISP to $200^{\circ}$ for $2 \mathrm{~h}$ before its use had no effect on Fe availability. When $2.3 \mathrm{~g}$ heated ISP (10 mg ascorbic acid) was compared with a similar formulation of untreated ISP, Fe absorption values were 0.135 and 0.099 respectively. Comparable values with $25 \mathrm{~g} \mathrm{ISP}$ (no ascorbic acid) were 0.067 and 0.058 .

7. Citric acid in amounts of $1-4 \mathrm{~g}$ had a dose related but limited enhancing effect on Fe absorption from $10 \mathrm{~g}$ ISP, with a rise from 0.011 (no citric acid) to 0.068 ( $4 \mathrm{~g}$ citric acid).

8. There was appreciable variability in the levels of $\mathrm{Fe}$ absorption in different studies, which suggested that unidentified manufacturing or preparative differences might be influencing the overall results.

The absorption of non-haem food iron is markedly affected by the relative proportions of promoters and inhibitors present in the diet (Bothwell et al. 1979). Ascorbic acid (Sayers et al. 1973; Derman et al. 1977; Hallberg, 1981) and meat (Layrisse et al. 1973; Hallberg, 1981) are the major promoters of non-haem-Fe absorption, while a number of inhibitors have been identified. These include phytates (Bothwell et al. 1979; Gillooly et al. 1984a), polyphenols (Disler et al. 1975; Gillooly et al. 1983, 1984a) and, to a lesser extent, certain constituents of dietary fibre (Gillooly et al. 1983). Another inhibitor that has recently been recognized is soya-bean protein (Cook et al. 1981; Morck et al. 1981, 1982; Hallberg \& Rossander, 1982; Gillooly et al. 1984b). Its overall effect on Fe nutrition is, however, complex since the reduction in the percentage absorption of non-haem-Fe is offset, in part at least, by the high Fe content of the soya-bean protein (Hallberg \& Rossander, 1982, 1984) 
Table 1. Constituents (per litre of prepared formula) of milk-and soya-bean-based infant formulas

\begin{tabular}{lcc}
\hline \hline & \multicolumn{2}{c}{ Infant formula } \\
\cline { 2 - 3 } & Miik-based & $\begin{array}{c}\text { Soya-bean- } \\
\text { based }\end{array}$ \\
\hline Protein (g) & 15 & 23 \\
Carbohydrate (g) & 70 & 68 \\
Fat (g) & 35 & 36 \\
Iron (mg) & $12 \cdot 7$ & $12 \cdot 7$ \\
Ascorbic acid (mg) & $58 \cdot 1$ & 58 \\
\hline
\end{tabular}

and by the fact that soya-bean protein enhances the absorption of haem-Fe (Lynch et al. 1985). It nevertheless remains important to identify the soya-bean inhibitor and to find ways of overcoming its effects, since the availability of the fortification Fe present in widely consumed and cost-effective infant formulas is adversely affected by the presence of the soya-bean protein contained within them (Cook et al. 1981; Gillooly et al. 1984b). The present study was done to examine further the effects of soya-bean protein on Fe absorption from an infant formula and to try to identify factors that might modify the effects of soya bean.

\section{EXPERIMENTAL}

Subjects

The 138 multiparous Indian housewives who took part in the study lived in two sub-economic housing areas close to Durban. None was pregnant or lactating and all were unpaid volunteers. Their ages ranged from 21 to 63 years (mean 45 years). A high prevalence of $\mathrm{Fe}$ deficiency amongst women has previously been documented in the community in which the subjects lived (Mayet et al. 1972). While there must be some reservations about extrapolating the findings in these adults to infancy, ethical and practical considerations precluded the study being done on infants themselves.

\section{Source of materials}

The constituents of the infant formulas are shown in Table 1. Both the soya-bean-based formula (Infasoy) and the milk-based formula (SMA) were obtained from Wyeth Laboratories (Isando, South Africa). The Fe in each was present as ferrous sulphate. The isolated soya-bean protein (ISP-1711; Ralston Purina Co., St Louis, Missouri, USA) was that used by Wyeth Laboratories as the soya-bean base in their infant formula, while soya-bean flour was obtained locally from Ruto Mills (Pretoria). L-Ascorbic acid (Analar) was purchased from BDH (Poole, Dorset) and citric acid from Merck (Darmstadt, W. Germany).

\section{Preparation of meals}

Infant formulas. Infant formula $(100 \mathrm{ml})$ was prepared by the addition of powder to cooled boiled water in the proportions recommended by the manufacturer $(13 \mathrm{~g}$ dry powder to $100 \mathrm{ml}$ water). Radioactive $\mathrm{Fe}$ in the form of ferric chloride (Amersham International plc, Amersham, Bucks) was mixed into the formula either as ${ }^{59} \mathrm{Fe}(2-3 \mu \mathrm{Ci})$ or as ${ }^{55} \mathrm{Fe}$ $(3 \mu \mathrm{Ci})$. In some studies both infant formulas were obtained from the manufacturer before the addition of the $\mathrm{Fe}$ and ascorbic acid. In these instances, sufficient $\mathrm{FeSO}_{4} \cdot 7 \mathrm{H}_{2} \mathrm{O}$ containing either ${ }^{59} \mathrm{Fe}$ or ${ }^{55} \mathrm{Fe}$ was added to give the same concentration of $\mathrm{Fe}$ 
$(1.27 \mathrm{mg} / 100 \mathrm{ml})$ as was present in the commercial formula. L-Ascorbic acid was added at the time of mixing to bring the ascorbic acid to the required concentration.

Isolated soya-bean protein (ISP). Since ISP is unpalatable, it was prepared as a 'milk shake' containing $2 \cdot 3 \mathrm{~g}$ ISP, $1.27 \mathrm{mg} \mathrm{Fe}$ (as $\mathrm{FeSO}_{4} \cdot 7 \mathrm{H}_{2} \mathrm{O}$ ), one-eighth teaspoon vanilla essence and two tablespoons white granulated sugar. The ingredients were mixed together in $100 \mathrm{ml}$ fresh full-cream milk. The quantities of $\mathrm{Fe}$ and ISP corresponded to those contained in $100 \mathrm{ml}$ of the soya-bean-based infant formula. Various amounts of ascorbic acid were added to the drink in different studies. In other experiments, the basic recipe was the same but greater amounts of ISP were used $(10 \mathrm{~g}$ or $25 \mathrm{~g})$.

Baked ISP. The ISP was mixed with sufficient water to make a thick paste and was then baked at $200^{\circ}$ for $2 \mathrm{~h}$. The resultant biscuit was subsequently ground into a powder. The baked soya-bean powder so derived was then prepared in the same way as the ISP ' $m$ ilk shake'.

\section{Administration of meals}

The subjects consumed two different drinks on consecutive mornings after an overnight fast. Apart from water, neither food nor drink was permitted for $4 \mathrm{~h}$ after taking the meal. The drinks tested were labelled with different isotopes of $\mathrm{Fe}$ on each day.

\section{Measurement of Fe absorption}

After 2 weeks, blood for the determination of ${ }^{59} \mathrm{Fe},{ }^{55} \mathrm{Fe}$, haemoglobin, serum $\mathrm{Fe}$, unsaturated Fe-binding capacity and serum ferritin was obtained from all subjects after they had fasted overnight. Each person then drank a standard $3 \mathrm{mg}$ dose of Fe as a solution of $\mathrm{FeSO}_{4} \cdot 7 \mathrm{H}_{2} \mathrm{O}$ labelled with $3 \mu \mathrm{Ci}{ }^{59} \mathrm{Fe}$ and containing $30 \mathrm{mg}$ ascorbic acid. Only water was permitted during the following $4 \mathrm{~h}$. Blood samples were obtained $14 \mathrm{~d}$ later and $\mathrm{Fe}$ absorption from the standard reference dose was determined from the increment in ${ }^{59} \mathrm{Fe}$ in the blood. This gave a measure of each person's capacity to absorb Fe and thus allowed for overall comparisons to be made between results in the individual studies (Rossander et al. 1979; Hallberg, 1981).

\section{Isotopic and chemical methods}

Duplicate $10 \mathrm{ml}$ blood samples and duplicate portions of standard Fe solutions were prepared for differential radioactive counting using a modification of the method of Eakins \& Brown (1966). The activities of ${ }^{55} \mathrm{Fe}$ and ${ }^{59} \mathrm{Fe}$ in the processed samples were determined in Insta-Gel scintillant (Packard Instrument Co., Illinois, USA) using a liquid-scintillation spectrometer (Packard-Tri-Carb AAA spectrometer, model no. 3375). The ${ }^{59} \mathrm{Fe}$ activity in the $4 \mathrm{ml}$ blood samples collected immediately before the reference Fe salt was administered and 2 weeks later was assessed against suitable standards using a Packard Auto Gamma scintillation spectrometer, model no. 5320. The absorption values were calculated on the assumption that $100 \%$ of the absorbed radioactivity was present in the haemoglobin of circulating erythrocytes (Bothwell et al. 1979) and that the blood volume for each subject was $65 \mathrm{ml} / \mathrm{kg}$ body-weight. The calculated absorption values were then expressed relative to the administered dose.

Haemoglobin concentrations were determined by the cyanmethaemoglobin technique. Serum Fe concentrations were measured using the International Committee for Standardization in Haematology (ICSH, 1978 a) method, as were unsaturated Fe-binding capacities (ICSH, 1978 b). Serum ferritin was measured using the ELISA immunoassay of Conradie \& Mbhele (1980). 


\section{Statistical methods}

Serum ferritin and Fe absorption results were log normally distributed and were expressed as geometric means and standard deviation ranges. Standard parametric methods for testing statistical inference were used.

\section{Ethical considerations}

Approval for the studies was obtained from the Committee for Research on Human Subjects of the Faculty of Medicine, University of the Witwatersrand, Johannesburg. Written consent was obtained from all subjects after the nature of the investigation had been fully explained to them by both an Indian field worker and a doctor. Each subject took part in one experiment only. It was calculated that if each test dose were completely retained, the total whole-body radiation dosage would be 143 mrems (Bothwell et al. 1979) which is $28 \%$ of the annual maximum permissible dose for members of the public (International Commission for Radiation Protection, 1960; South African Bureau of Standards, 1972). In practice, the percentage absorbed was much less, which would make the radiation exposure proportionately less.

\section{RESULTS}

Fe status of various groups of women

In all, thirteen different $\mathrm{Fe}$ absorption studies were done with groups of women varying from six to sixteen in number (Tables 2 and 3). They were moderately homogeneous in terms of their haemoglobin and Fe measurements. The mean haemoglobin concentrations of the groups varied between 116 and $137 \mathrm{~g} / 1$, the transferrin saturation between 20.0 and $29 \cdot 1 \%$ and the serum ferritin concentration between 11.2 and $35.3 \mu \mathrm{g} / 1$. Absorption of Fe from the $3 \mathrm{mg}$ reference dose of $\mathrm{Fe}$ ascorbate varied between 0.283 and 0.652 . These various findings indicated that the Fe status of most of the women studied was one in which the haemoglobin concentration was maintained but $\mathrm{Fe}$ stores were decreased or absent. $\mathrm{Fe}$ absorption in most of the groups was also in the range associated with borderline $\mathrm{Fe}$ deficiency (Rossander et al. 1979).

\section{Influence of ascorbic acid on Fe absorption from milk-based and soya-bean-based infant formulas}

The addition of $8.4 \mathrm{mg}$ ascorbic acid significantly increased the geometric mean absorption of $\mathrm{Fe}$ in the milk-based formula from 0.031 to $0.155(t 2.80, P<0.003)$ (Table 2(A)). A further increase was noted in ten subjects in whom the effects of $8.4 \mathrm{mg}$ and $25 \mathrm{mg}$ ascorbic acid were compared $(0.183$ and 0.395 respectively; $t 3.37, P<0.01)$ (Table 2 (B)). In contrast, ascorbic acid at a dose of $5.8 \mathrm{mg}$ had an insignificant effect when added to the basal soya-bean formula $(0.041 v .0 .030 ; t 0.93, P>0.1)$ (Table $2(C))$. The effects of 10 and $25 \mathrm{mg}$ ascorbic acid were studied in another eleven subjects (Table 2(D)). The geometric mean absorptions were 0.036 and 0.060 respectively $(t 1.42, P>0.1)$.

The relative availability of $\mathrm{Fe}$ in milk-based and soya-bean-based formulas was directly compared in two studies. In the absence of ascorbic acid, the geometric mean absorptions in twelve subjects were 0.083 and 0.044 respectively (Table 2(E)), while the addition of $5.8 \mathrm{mg}$ ascorbic acid was associated with values of 0.119 and 0.018 respectively in a further eight subjects (Table $2(\mathrm{~F})$ ). Fe absorption from the milk-based formula was significantly greater in both experiments $(t 2.81, P<0.025$ and $t 2.78, P<0.05$ respectively). 


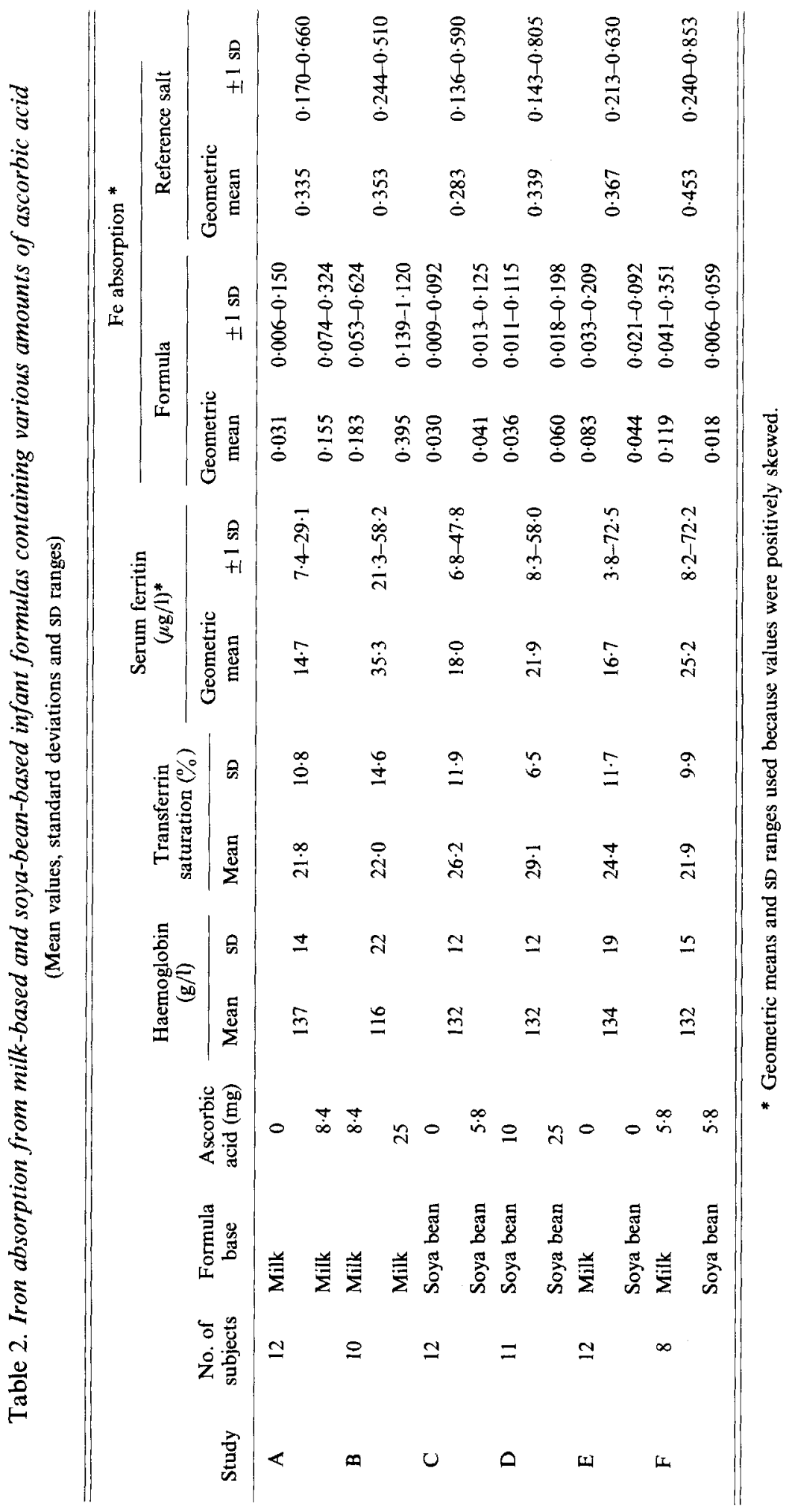




\section{Influence of various factors on Fe absorption from soya-bean products}

In the first experiment on eleven subjects, Fe absorption from the soya-bean-based formula was compared with that from a milk drink containing the same amounts of ISP and ascorbic acid (Table 3(A)). The geometric mean Fe absorption from the ISP was significantly greater than that from the formula $(0.113$ and 0.075 respectively; $t 2.55$, $P<0 \cdot 05$ ). Since it seemed possible that the increased Fe absorption was due to some effect of the milk, a direct comparison was made in six subjects between the absorption of the soya-bean formula $(5.8 \mathrm{mg}$ ascorbic acid) given in milk and in water (Table 3(B)). No difference in the geometric mean $\mathrm{Fe}$ absorptions was found $(0.043$ and 0.060 respectively; $t 0 \cdot 06, P>0.5$ ).

The influence of the extraction procedure was examined in a third experiment on twelve subjects (Table $3(\mathrm{C})$ ). The absorption of Fe from a drink containing $10 \mathrm{~g}$ ISP (total $\mathrm{Fe}$ content $3.1 \mathrm{mg}$ ) was compared with that from one containing the same amount of protein as soya-bean flour. Ascorbic acid ( $30 \mathrm{mg}$ ) was present in each of the drinks. The geometric mean Fe absorption was significantly greater $(t 2 \cdot 25, P<0.05)$ from the ISP than from the soya-bean flour $(0.044$ and 0.027 respectively).

Soya-bean contains a powerful heat-labile tryptic inhibitor which is destroyed by heating during the preparation of soya-bean products (International Nutritional Anemia Consultative Group (INACG), 1982). Since it was possible that some residual activity might still be present, ISP was heated to $200^{\circ}$ for $2 \mathrm{~h}$ and the absorption of Fe given with it was compared with that from the untreated protein. In one experiment on six subjects, $25 \mathrm{~g}$ ISP (total $\mathrm{Fe}$ content $5 \mathrm{mg}$ ) was given in $125 \mathrm{ml}$ milk (Table 3(D)). The geometric mean absorption of 0.067 from the heated ISP was very similar to the value of 0.058 from the unheated protein $(t 1 \cdot 34, P>0 \cdot 1)$. In the other experiment, a much smaller amount $(2 \cdot 3 \mathrm{~g}$ ISP) was given together with $10 \mathrm{mg}$ ascorbic acid (Table 3(E)). The Fe was well absorbed, with the geometric mean absorptions from the heated and unheated ISP being quite similar $(0 \cdot 135$ and 0.099 respectively; $t 1 \cdot 34, P>0 \cdot 1)$.

The effects of citric acid on Fe availability from ISP were studied in two experiments (Table $3(\mathrm{~F}, \mathrm{G})$ ). In the first, $10 \mathrm{~g}$ ISP (total Fe content $3.1 \mathrm{mg}$ ) was given alone and with $1 \mathrm{~g}$ citric acid. Relevant geometric mean $\mathrm{Fe}$ absorption values were 0.011 and 0.026 respectively. The effects of 2 and $4 \mathrm{~g}$ citric acid on Fe absorption from $10 \mathrm{~g}$ ISP were tested in a further experiment. The enhancement of $\mathrm{Fe}$ absorption appeared to be dose related; the value was 0.048 with $2 \mathrm{~g}$ and 0.068 with $4 \mathrm{~g}(t 2.48, P<0.05)$.

\section{DISCUSSION}

Initial studies on the absorption of $\mathrm{Fe}$ in the presence of soya-beans gave conflicting results, with some showing good availability (Layrisse et al. 1969; Sayers et al. 1973) and others relatively poor availability (Ashworth \& March, 1973; Björn-Rasmussen et al. 1973). The confusion appeared to be resolved in a series of studies by Cook and co-workers in which they demonstrated that the availability of Fe in maize-soya bean-milk was low (Morck et al. 1981), and Fe absorption from meals containing ISP was significantly less than that from meals containing egg albumin or casein (Cook et al. 1981). They showed further that the inhibitor of Fe absorption was not removed by purification but could be partially overcome by ascorbic acid (Morck et al. 1982). These latter observations were extended by Gillooly et al. $(1984 a, b)$, who found that the enhancing effects of ascorbic acid on Fe absorption were several-fold less in the presence of soya-bean than they were with milk. Similar findings were noted in the present study, in which different amounts of ascorbic acid were given together with milk-based and soya-bean-based infant formulas 
(Table 2). It should be noted that Fe absorption from the soya-bean formulas with or without ascorbic acid was low despite the presence of only a small amount of protein $(2 \cdot 3 \mathrm{~g}$ ISP; Table 1).

In the second part of the study, attempts were made to identify the factor(s) responsible for the low availability of $\mathrm{Fe}$ when given together with an infant soya-bean formula. In the first group of experiments, the formulation of the soya-bean-protein meal was evaluated. The observation of greater absorption from ISP (in milk) than from the formula suggested that milk might be enhancing absorption (Table 3(A)) but this was not confirmed when ISP in milk was compared with ISP in water (Table 3(B)). Contrary to previous findings (Cook et al. 1981), a more-refined soya-bean product (ISP in milk) was less inhibitory than a less-refined soya-bean product (soya-bean flour in milk) (Table 3(C)). A second question was addressed in two further experiments. The enhancing effect of meat on Fe absorption (Layrisse et al. 1969) has been ascribed to the release on digestion of chelating substances, such as cysteine, which form soluble complexes with Fe (Martinez-Torres et al. 1981; Layrisse et al. 1984). In this context, soya-bean contains a strong heat-labile tryptic inhibitor (INACG, 1982), which theoretically might lead to a diminished availability of amino acids as a result of inadequate protein digestion. Since it seemed possible that the inhibitor might not be fully removed during the manufacturing process, ISP was heated to $200^{\circ}$ for $2 \mathrm{~h}$ before testing. With $25 \mathrm{~g}$ ISP and no ascorbic acid, heating had no effect (Table 3(D)). The experiment was repeated with a smaller amount of ISP $(2.3 \mathrm{~g})$ and $10 \mathrm{mg}$ ascorbic acid (Table 3(E)). Overall $\mathrm{Fe}$ absorption was greater under these circumstances but the differences were not significant.

As the factor(s) in the soya-bean formula responsible for inhibiting Fe absorption were not identified, a study was done to demonstrate a more effective promoter of $\mathrm{Fe}$ absorption than ascorbic acid. The in vitro finding that citric acid forms a soluble complex with $\mathrm{Fe}$ at $\mathrm{pH} 6$ in the presence of maize-soya bean-milk was of potential relevance (Rizk \& Clydesdale, 1985). Fe absorption studies using $10 \mathrm{~g}$ ISP and 0, 1000, 2000 and $4000 \mathrm{mg}$ citric acid showed a progressive though modest rise in Fe absorption (Table 3(F, G)). While these findings confirm the enhancing action of citric acid on non-haem-Fe absorption (Gillooly et al. 1983), its effects are many times less than those of ascorbic acid on a weight-for-weight basis.

Ascorbic acid has been shown to exert a marked enhancing effect on $\mathrm{Fe}$ absorption when it is added to cereal meals (Derman et al. 1977) and to infant milk and cereal formulas (Derman et al. 1980). Both this and a previous study (Gillooly et al. 1984 b) demonstrate that its effects in the presence of soya-bean protein are at best modest, even when present in relatively large amounts. It is, therefore, important that the inhibitor(s) of $\mathrm{Fe}$ absorption present in soya-bean be identified and removed. In this connection, the in vitro observations of Kane \& Miller (1984) are of potential importance. They showed that low-molecularweight digestion-product fractions from beef enhanced the dialysis of $\mathrm{Fe}$, while similar products from soya-bean protein did not. They suggested that the net effect of a protein on $\mathrm{Fe}$ availability depends on the nature of the complexes formed between $\mathrm{Fe}$ and the protein-digestion products.

Certain results in the present study suggested that the behaviour of the protein was not always predictable. Although the women studied were homogeneous in terms of their haemoglobin concentrations and Fe status, there were several studies in which anomalous results were obtained. For example, in the various studies which were done with ISP $(2 \cdot 3 \mathrm{~g}+5.8 \mathrm{mg}$ ascorbic acid), either as the formula or with milk or water, there was a fairly wide range of $\mathrm{Fe}$ absorption results $(0 \cdot 018-0 \cdot 113)$. No reason for this variation was found. It is, however, of interest that similar discrepancies were noted when the first Fe absorption studies were done on soya beans (INACG, 1982). 
In putting the present findings into perspective, it is important to distinguish between the use of soya-bean products in infant formulas and as a more general protein source. In infant formulas the major $\mathrm{Fe}$ component is added as a fortifier and the presence of soya bean seriously inhibits its absorption. However, in situations where soya-bean products are used as meat substitutes the situation is different. The soya bean contains relatively large amounts of $\mathrm{Fe}$ and although the proportion of Fe absorbed is low, the total amount retained is adequate (Hallberg \& Rossander, 1984). Furthermore, soya-bean protein enhances the absorption of haem-Fe (Lynch et al. 1985).

\section{REFERENCES}

Ashworth, A. \& March, Y. (1973). British Journal of Nutrition 39, 577-584.

Björn-Rasmussen, E., Hallberg, L. \& Walker, R. (1973). American Journal of Clinical Nutrition 26, 1311-1319. Bothwell, T. H., Charlton, R. W., Cook, J. D. \& Finch, C. A. (1979). Iron Metabolism in Man Oxford: Blackwell. Conradie, J. D. \& Mbhele, B. E. L. (1980). South African Medical Journal 57, 282-287.

Cook, J. D., Morck, T. A. \& Lynch, S. R. (1981). American Journal of Clinical Nutrition 26, 2622-2629.

Derman, D. P., Bothwell, T. H., MacPhail, A. P., Torrance, J. D., Bezwoda, W. R., Charlton, R. W. \& Mayet, F. (1980). Scandinavian Journal of Haematology 25, 193-201.

Derman, D., Sayers, M., Lynch, S. R., Charlton, R. W., Bothwell, T. H. \& Mayet F. (1977). British Journal of Nutrition 38, 261-269.

Disler, P. B., Lynch, S. R., Charlton, R. W., Torrance, J. D., Bothwell, T. H., Walker, R. B. \& Mayet, F. (1975). Gut 16, 193-200.

Eakins, J. D. \& Brown, D. A. (1966). International Journal of Applied Radiation Isotopes 17, 391-397.

Gillooly, M., Bothwell, T. H., Charlton, R. W., Torrance, J. D., Bezwoda, W. R., MacPhail, A. P. \& Derman, D. P (1984a). British Journal of Nutrition 51, 37-46.

Gillooly, M., Bothwell, T. H., Torrance, J. D., MacPhail, A. P., Derman, D. P., Bezwoda, W. R., Mills, W. \& Charlton, R. W. (1983). British Journal of Nutrition 49, 331-342.

Gillooly, M., Torrance, J. D., Bothwell, T. H., MacPhail, A. P., Derman, D., Mills, W. \& Mayet, F. (1984b). American Journal of Clinical Nutrition 40, 522-527.

Hallberg, L. (1981). Annual Review of Nutrition 1, 123-147.

Hallberg, L. \& Rossander, L. (1982). American Journal of Clinical Nutrition 36, 514-520.

Hallberg, L. \& Rossander, L. (1984). American Journal of Clinical Nutrition 39, 577-583.

International Commission for Radiation Protection. (1960). Report of Committee II on Permissible Doses of Internal Radiation. ICRP Publication no. 2. Oxford: Pergamon Press.

International Committee for Standardization in Haematology (1978a). British Journal of Haematology 38, 291-294.

International Committee for Standardization in Haematology (1978b). British Journal of Haematology 38, $281-290$.

International Nutritional Anemia Consultative Group (1982). The Effects of Cereals and Legumes on Iron Bioavailability. Washington, DC: Nutrition Foundation.

Kane, A. P. \& Miller, D. D. (1984). American Journal of Clinical Nutrition 39, 393-401.

Layrisse, M. C., Cook, J. D., Martinez, C., Roche, M., Kuhn, I. N., Walker, R. B. \& Finch, C. A. (1969), Blood 33, $430-443$.

Layrisse, M. C., Martinez-Torres, C., Cook, J. D., Walker, R. B. \& Finch, C. A. (1973). Blood 41, 333-352.

Layrisse, M. C., Martinez-Torres, C., Leets, R., Taylor, P. \& Ramirez, J. (1984). Journal of Nutrition 114, $217-223$.

Lynch, S. R., Dassenko, S., Morck, T. A., Beard, J. L. \& Cook, J. D. (1985). American Journal of Clinical Nutrition 41, 13-20.

Martinez-Torres, C., Romano, E. \& Layrisse, M. (1981). American Journal of Clinical Nutrition 34, 322-327.

Mayet, F. G. H., Adams, E. B., Moodley, T., Kleber, E. E. \& Cooper, S. K. (1972). South African Medical Journal 46, $1427-1430$.

Morck, T. H., Lynch, S. R. \& Cook, J. D. (1982). American Journal of Clinical Nutrition 36, 219-228.

Morck, T. H., Lynch, S. R., Skikne, B. S. \& Cook, J. D. (1981). American Journal of Clinical Nutrition 34, 2630-2634.

Rizk, S. W. \& Clydesdale, F. M. (1985), Journal of Food Science 50, 1088-1091.

Rossander, L., Hallberg, L. \& Björn-Rasmussen, E. (1979). American Journal of Clinical Nutrition 32, $2484-2489$.

Sayers, M. H., Lynch, S. R., Jacobs, P., Charlton, R. W., Bothwell, T. H., Walker, R. B. \& Mayet, F. (1973). British Journal of Haematology 24, 209-218.

South African Bureau of Standards (1972). Code of Practice for Medical Use of Ionizing Radiations document no. 07. 